\title{
Compatibility between Disturbance Emission and Argentinian Power Quality Regulations in Iron and Steel Industries
}

\author{
P. E. Issouribehere, J. C. Barbero, G.A. Barbera, and F. Issouribehere, Member, IEEE
}

\begin{abstract}
Measurements and studies developed to mitigate harmonic and flicker emission to public networks are presented in this paper. Two different real cases are analyzed. The first one is a new electric furnace with low power factor, which is added to the load consisting of other existing furnaces. The installation had a reactive compensation bank which, according to measurements and studies, would cause harmonic resonance with weak public networks. As technical solution, a dumped $\mathrm{C}$-type filter was designed, taking advantage of the existing bank, to comply with limits established by ENRE 99/97 and IEEE 519/1992. The other case deals with a $2.5 \mathrm{MW}$ electric arc furnace fed from the public MV network. The carried out measurements harmonics, voltage and current unbalances, active and reactive power, power factor and flicker determined that the high flicker level was the most critical disturbance. In addition, the compensation factors required to comply with reference levels and also to determine the dimension of the suitable static compensator were calculated.
\end{abstract}

Index Terms - Electromagnetic Compatibility. Flicker. Furnaces. Harmonic distortion. Power Quality.

\section{INTRODUCTION}

A rgentinian regulations follow severe international criteria for disturbances emitted from disturbing loads to the network. This is in order to ensure the electromagnetic compatibility between the supplier and customers.

Meeting these regulations frequently requires studying local measures to mitigate the perturbations injected by disturbing loads into the electric distribution system.

Experiences developed in two real cases based on measurements and studies, carried out to mitigate harmonic and flicker emission, are presented in this paper.

The first case corresponds to a new electric furnace of submerged anode and low power factor type, in an Argentinian plant of products for steel making. Such furnace was added to the load represented by other existing furnaces.

The plant is fed from the public MV distribution network at $13.2 \mathrm{kV}$. The new electrical installation was designed for a 14 MW low power factor furnace.

Pedro E. Issouribehere, Juan C. Barbero, Gustavo A. Barbera and Fernando Issouribehere are with IITREE-LAT, Facultad de Ingeniería, Universidad Nacional de La Plata. (B1900AMF) 48 y 116, La Plata. Argentina. (e-mail:.iitree@iitree-unlp.org.ar).
The installation had a 14 MVAr modular compensation bank to compensate reactive energy which, according to studies and measurements, would cause some resonance with the network. To take advantage of the existing bank, dumped C-type and third order filters were simulated. Thus, limits established by ENRE 99/97 and IEEE 519/1992 were fulfilled.

The other case deals with a $2.5 \mathrm{MW}$ electric arc furnace for steel melting fed from a $13.2 \mathrm{kV}$ network. Measurements of voltage and current harmonics and unbalances, active and reactive powers, power factor and flicker were carried out. The results determined that flicker was the most critical disturbance. Then, it was calculated the compensation factor required to comply with international and Argentinian reference levels and to determine the suitable static compensator size.

One of the purposes of this paper is to present technical solutions for both cases.

\section{CASE I: HARMONiC RESONANCE BETWEen THE REACTIVE COMPENSATION BANK AND THE NETWORK}

An electric furnace of submerged anode and low power factor type was added to other existing furnaces fed from different supplies. A power factor compensation bank was installed with the new furnace.

Since it was suspected that the connection of the compensation bank would cause some resonance with the network, it was not possible to connect it during the measurements. Therefore, the effect of the capacitors had to be studied by simulations.

\section{A. Measurements}

In order to characterize the phenomenon, measurements were carried out for two periods. In each period, the furnace was melting different products.

The recorded data $\left(P_{s t}\right.$, THD and harmonic currents) yield:

- Flicker: $P_{s t}$ value not exceeded during $95 \%$ of the time (worst phase) was $P_{s t 95 \%}=1.01$ in the first period and $P_{s t 95 \%}=0.57$ in the second. The limit established by Argentinian regulation is $P_{s t 95 \%}=1$. 